\title{
Bacteriuria and vitamin D deficiency: a cross sectional study of 385 nursing home residents
}

Rebeka Arnljots ${ }^{1,2,3^{*}}$, Egill Snaebjörnsson Arnljots ${ }^{1,4}$, Jörgen Thorn² ${ }^{2}$ Marie Elm ${ }^{5}$, Michael Moore ${ }^{6}$ and Pär-Daniel Sundvall ${ }^{1,2,7}$

\begin{abstract}
Background: Up to half of elderly people at nursing homes have asymptomatic bacteriuria, and concentrations of 25-hydroxyvitamin D (25OHD) are generally low. Vitamin D is a modulator of the immune system and involved in protection of the epithelium in the urinary tract as well. The objective was to determine a possible association between bacteriuria and vitamin D deficiency among elderly people at nursing homes.

Methods: Cross-sectional study: Voided urine specimens and blood samples for cultivation and analysis of 25OHD were collected from elderly people at nursing homes in Sweden. Exclusion criteria were: urinary catheter, ongoing antibiotic treatment, incontinence or dementia too severe to provide a voided urine specimen or leave a blood sample, unwillingness to participate or terminal illness. Urine cultures and serum 25OHD concentrations were outcome measures and the association of bacteriuria with vitamin D deficiency was determined by logistic regression.

Results: Twenty-two nursing homes participated and 385 of 901 elderly people provided voided urine specimens and blood samples. The mean age was 87 (SD 6.7), 69\% women, 19\% received vitamin D supplement, 13\% had diabetes mellitus, and $54 \%$ were diagnosed with dementia. There was significant growth of potentially pathogenic bacteria in $32 \%(123 / 385)$ of voided urine specimens. Escherichia coli were present in $83 \%$ of positive urine cultures. The mean concentration of $25 \mathrm{OHD}$ in serum was $35 \mathrm{nmol} / \mathrm{L}$ (SD 21). Thirty-seven per cent $(143 / 385)$ had $25 \mathrm{OHD}<25 \mathrm{nmol} / \mathrm{L}$, and $3.1 \%(12 / 385) 25 \mathrm{OHD}<12.5 \mathrm{nmol} / \mathrm{L}$. No association between bacteriuria and $25 \mathrm{OHD}<25 \mathrm{nmol} / \mathrm{L}$, OR $1.4(0.86-2.3$; $p=0.18)$ adjusted for age, gender, diabetes mellitus and dementia was found. However, if using $25 \mathrm{OHD}<12.5 \mathrm{nmol} / \mathrm{L}$ as a cut-off for vitamin D deficiency the adjusted odds-ratio was $4.4(1.1-17 ; p=0.031)$.
\end{abstract}

Conclusions: Bacteriuria and vitamin D deficiency was common. No association between bacteriuria and 25OHD $<25$ $\mathrm{nmol} / \mathrm{L}$ was found. If using $25 \mathrm{OHD}<12.5 \mathrm{nmol} / \mathrm{L}$ as cut-off for vitamin $\mathrm{D}$ deficiency there was an association. However, this has to be interpreted with caution as causality cannot be evaluated as well as only few residents had $25 \mathrm{OHD}<12.5 \mathrm{nmol} / \mathrm{L}$.

Keywords: Vitamin D, Bacteriuria, Urinary tract infections, Homes for the aged, Nursing homes, Frail elderly

\footnotetext{
*Correspondence: rebeka.arnljots@vgregion.se

'Research and Development Primary Health Care, Region Västra Götaland, Research and Development Centre Södra Älvsborg Sweden, Sven Eriksonsplatsen 4, SE-503 38 Borås, Sweden

${ }^{2}$ Department of Public Health and Community Medicine/Primary Health

Care, Institute of Medicine, Sahlgrenska Academy at the University of

Gothenburg, Box 454, SE-405 30 Gothenburg, Sweden

Full list of author information is available at the end of the article
}

(c) The Author(s). 2020 Open Access This article is distributed under the terms of the Creative Commons Attribution 4.0 International License (http://creativecommons.org/licenses/by/4.0/), which permits unrestricted use, distribution, and reproduction in any medium, provided you give appropriate credit to the original author(s) and the source, provide a link to the Creative Commons license, and indicate if changes were made. The Creative Commons Public Domain Dedication waiver (http://creativecommons.org/publicdomain/zero/1.0/) applies to the data made available in this article, unless otherwise stated. 


\section{Background}

Urinary tract infection (UTI) is the most common infection in residents of nursing homes for the elderly. Nearly half the residents will also have asymptomatic bacteriuria (ASB) [1-3]. Differentiating infection from asymptomatic carriage is often difficult leading to inappropriate prescribing of antibiotics. Changes associated with ageing such as multimorbidity, weakening of the immune system and decreased cognitive function, increase the risk of developing UTI $[3,4]$.

Studies have shown that serum concentrations of vitamin D in elderly individuals are in the lower intervals and even lower among nursing home residents where vitamin $\mathrm{D}$ deficiency is common [4-8]. Sweden is at a latitude of $55-69^{\circ} \mathrm{N}$, where dermal synthesis of vitamin D occurs solely during the summer months [9]. Despite a lack of consensus on the optimum serum concentrations of vita$\min \mathrm{D}[10,11]$, 25-hydroxyvitamin $\mathrm{D} \quad(25 \mathrm{OHD}) \geq 50$ $\mathrm{nmol} / \mathrm{L}$ is recommended for those $>65$ [11].

Vitamin D is a modulator of the immune system, influencing innate and acquired immune reactions, and is involved in protection of the epithelium of the urinary tract $[4,12-14]$. The urinary tract is usually considered sterile apart from the urinary meatus [14]. Several protective factors including antimicrobial peptides (AMP) and the innate immune system act to prevent infections of the urinary tract. Vitamin D supports and enhances these systems. The innate immune system is the firstline rapid response barrier to prevent microbial invasion consisting of receptors, proteins and cells that quickly recognize and neutralize foreign bodies. A fast innate immune response is important in preventing the development of UTI, since the adaptive immune system is only later activated. AMPs are synthesized by immune and epithelial cells and offer quick protection by binding foreign microbes and neutralizing them [12, 14, 15].

It has been demonstrated that the most important AMP in the urinary tract is cathelicidin, synthesized by urinary epithelium and released immediately upon exposure to foreign microbes, such as $E$. coli, thus preventing infection $[12,14]$. Studies indicate that vitamin D stimulates the production of cathelicidin in the urinary bladder, and there is some evidence supporting positive effects of vitamin D on UTI in children, pre- and postmenopausal women, pregnant women, prediabetic patients and renal transplant patients [12, 16-21]. There is uncertainty concerning the association between vitamin $\mathrm{D}$ concentrations and bacteriuria among elderly residents in nursing homes.

Previous studies have shown an increased frequency of symptomatic UTI in those earlier identified with asymptomatic bacteriuria (ASB) and ASB causes a low grade inflammation of the epithelium in the urinary tract [2224]. As the population ages the burden of ASB and UTI will increase, posing a risk for increased antibiotic use and subsequent resistance to urinary tract antibiotics [3, 4]. Potentially, vitamin D could be a complement in the prevention of ASB and UTI.

The objective was to determine a possible association between bacteriuria and vitamin D deficiency among elderly people at nursing homes.

\section{Methods}

From January to March 2012 in southwestern Sweden (latitude $57.58^{\circ} \mathrm{N}-57.82^{\circ} \mathrm{N}$ ), blood and urine samples were gathered, and a case report form was filed for all included residents of 22 nursing homes. Detailed verbal and written information regarding study procedure was given to the nurses. The Regional ethical review board of Gothenburg University (reference number 578-11) approved the study. Data was collected together with data from other studies $[5,25,26]$. The data presented on Vitamin D and bacteriuria in this manuscript has not been published before.

\section{Inclusion and exclusion criteria}

Inclusion criteria were permanent residency in nursing homes for the elderly, regardless of gender and duration of residency, nursing home resident during the study, approved participation, absence of indwelling urinary catheter, ability to leave a voided urine sample and in case of dementia inclusion only if cooperative when collecting urine and blood samples.

Exclusion criteria were urostomy, terminal illness, intermittent catheterisation, ongoing antibiotic treatment and discontinued study participation.

\section{Statement of consent}

Included residents were provided both written and verbal information. Informed approval was obtained from decision-capable individuals. However, many participants had varying forms of dementia. If a resident lacked comprehension of the provided information, they participated only if they or their surrogates did not refuse participation after the provision of information regarding the study. This procedure was approved by the Regional ethical review board of Gothenburg University (reference number 578-11).

\section{Case report form}

There was a predetermined date for the gathering of blood and urine samples from included residents. Blood and urine samples were collected on the same day. Furthermore, on the same day nurses registered age, gender, vitamin D supplementation, dementia or diabetes, temperature measured by an ear thermometer, and any recent onset of urinary tract symptoms. A dementia diagnosis required a comprehensive anamnesis and 
medical examination, laboratory tests, cognitive function test, and frequently neuroimaging.

\section{Laboratory tests \\ Concentrations of $250 \mathrm{HD}$}

A nurse gathered blood samples from participants, which were analysed at Södra Älvsborg Hospital in Borås, Sweden, according to their established procedures. The samples were chilled prior to transport arriving for analysis within $24 \mathrm{~h}$. Serum concentrations of $25 \mathrm{OHD}$ were analyzed by the LIAISON $^{\circ} 25 \mathrm{OH}^{2}$ itamin D TOTAL Assay (DiaSorin Inc., Stillwater, USA) using chemiluminescent immunoassay (CLIA) technology for the quantitative determination of 25hydroxyvitamin D. The range of the Assay was 4.0-150 ng/ mL. This analysis was accredited at Södra Älvsborg Hospital.

\section{Urine culture}

Nursing staff members gathered a mid-stream morning urine sample, or a voided urine specimen with the longest possible bladder incubation time. The specimens were chilled prior to transport arriving at the laboratory within a day. The specimens were then cultured at Södra Älvsborg Hospital according to their established procedures using the outcomes of the dipstick urinalyses and information regarding UTI symptoms. The technical procedure is described in detail in a previously published study of bacteriuria and interleukin- 6 concentrations, were data was collected together with this study [25]. Dipstick urinalyses and visual readings of the urine dipstick Multistix 5 (Siemens Healthcare Laboratory Diagnostics) were carried out at the nursing home. All urine specimens were cultured regardless of the outcome of dipstick urinalysis.

\section{Statistical analysis}

The population was described according to the number of individuals, age, gender, 25OHD-concentrations, bacterial findings in urine cultures, vitamin D supplementation, and dementia or diabetes.

One objective was to describe vitamin D concentrations among residents with or without bacteriuria. Concentrations of 25OHD were compared between residents with positive and negative urine cultures using Student's t-test. The proportion of residents with vitamin D deficiency defined by four cut-off concentrations was presented for all residents and differentiated by bacteriuria or not: $25 \mathrm{OHD}<12.5 \mathrm{nmol} / \mathrm{L},<25 \mathrm{nmol} / \mathrm{L},<50 \mathrm{nmol} / \mathrm{L}$ and $<75 \mathrm{nmol} / \mathrm{L}$.

Another objective was to establish whether bacteriuria was associated with vitamin $\mathrm{D}$ deficiency defined as $25 \mathrm{OHD}<25 \mathrm{nmol} / \mathrm{L}$ and $25 \mathrm{OHD}<12.5 \mathrm{nmol} / \mathrm{L}$ respectively, adjusted for age, gender, dementia and diabetes. Both adjusted and unadjusted logistic regressions were carried out.
All analyses employed the IBM SPSS Statistics version 22 (IBM Corporation, Armonk, New York, USA) and $p<0.05$ was considered statistically significant.

\section{Results \\ Study population}

Seven hundred of nine hundred-one residents in 22 nursing homes met the inclusion criteria, and 459/700 (66\%) agreed to participate (Fig. 1). 385 residents, 266 (69\%) women and 119 (31\%) men provided urine specimens, blood samples and case report forms. The mean age was 87 years-old (SD 6.7), and the range 63-100 with women (mean 87, SD 6.5, range 63-99) somewhat older than men (mean 85, SD 6.9, range 69-100) ( $p=0.0091)$.

Fifthy-four percent (208/385) of participating residents had dementia, and 13\% (51/385) diabetes (Table 1). Vitamin D supplementation was noted in 19\% (73/385), and $82 \%(60 / 73)$ had colecalciferol (vitamin $\left.\mathrm{D}_{3}\right)$, and $18 \%$ (13/73) ergocalciferol (vitamin $\mathrm{D}_{2}$ ).

Prevalence of newly onset symptoms from the urinary tract during the last week was dysuria $0.78 \%$ (3/385), urinary urgency $1.3 \%$ (5/385), and urinary frequency $0.52 \%(2 / 385)$. All participants had a temperature $<38^{\circ} \mathrm{C}$.

\section{Serum 250HD concentrations}

Serum 25OHD concentrations, irrespective of vitamin D supplementation: mean $35 \mathrm{nmol} / \mathrm{L}$ (SD 21, median 28, range $4-125), 3.1 \%(12 / 385)<12.5 \mathrm{nmol} / \mathrm{L}$ and $37 \%$ $(143 / 385)<25 \mathrm{nmol} / \mathrm{L}$. Concentrations of serum $25 \mathrm{OHD}$ are presented in Table 1 .

\section{Bacterial findings}

Significant growth of potentially pathogenic bacteria was seen in $32 \%(123 / 385)$ of urine cultures. E. coli was present in $83 \%(102 / 123)$, the most common bacterial finding in positive urine cultures, the second most common finding was Klebsiella spp., present in 8.1\% (10/123), and Proteus spp. were present in 1.6\% (2/123). Other species had low prevalence, $\leq 1.6 \%$ for each species.

\section{Bacterial findings among residents with vitamin D deficiency}

Among residents with $25 \mathrm{OHD}<25 \mathrm{nmol} / \mathrm{L} 36 \%$ (52/ 143) had bacteriuria (Table 1). In those with $<12.5$ $\mathrm{nmol} / \mathrm{L}, 58 \%$ (7/12) had bacteriuria (Table 1$)$. There was no difference in vitamin $\mathrm{D}$ concentrations among residents with or without bacteriuria $(p=0.76)$ : mean concentrations of vitamin D were $34 \mathrm{nmol} / \mathrm{L}$ (SD 22) among residents with bacteriuria versus $35 \mathrm{nmol} / \mathrm{L}$ (SD 20) in those without bacteriuria. 


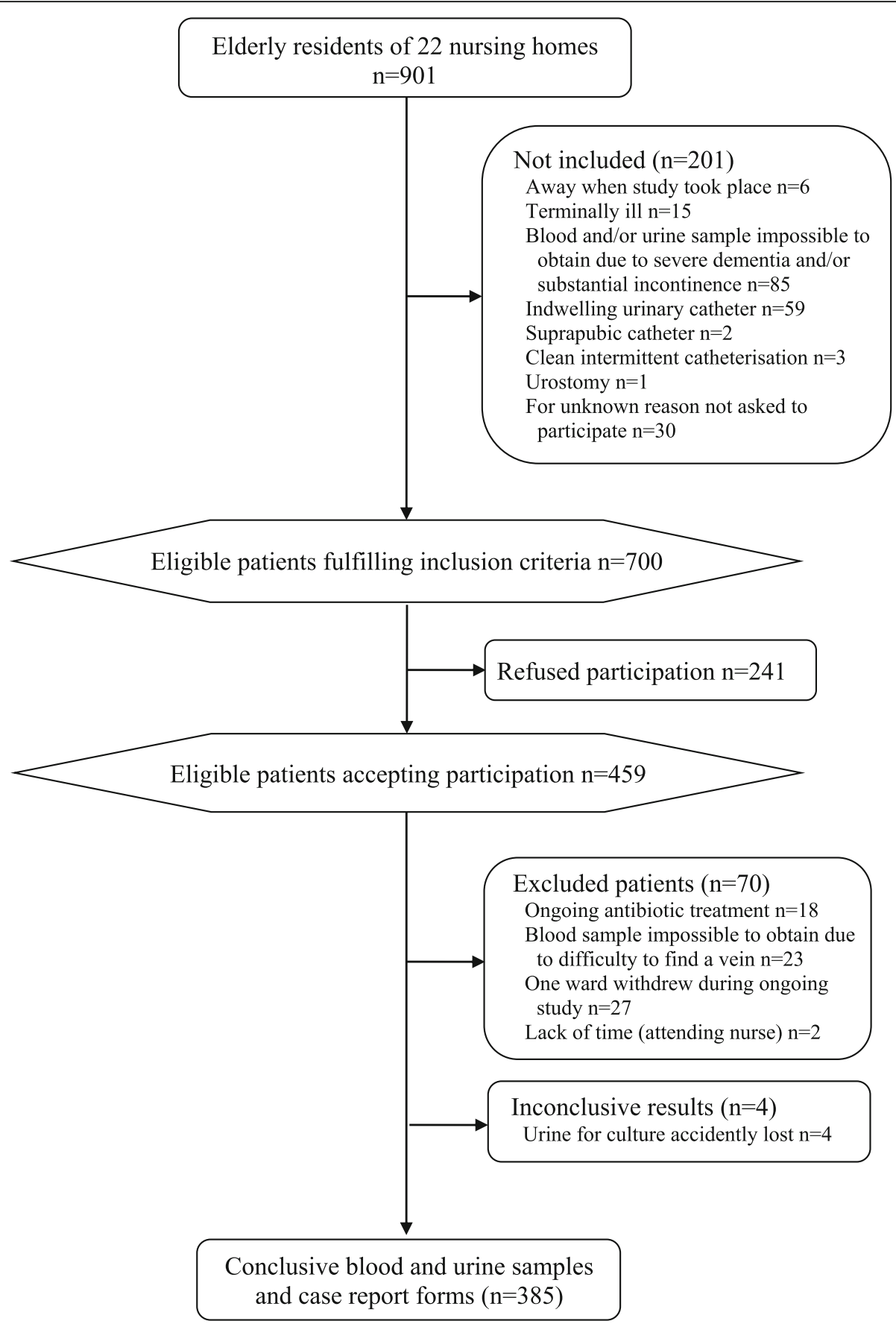

Fig. 1 Participant flow chart

Factors associated with bacteriuria with cut-off $250 \mathrm{HD}<$ $25 \mathrm{nmol} / \mathrm{L}$

Adjusted OR (95\% CI; $p$-value) for possible predictors of bacteriuria: $25 \mathrm{OHD}<25 \mathrm{nmol} / \mathrm{L} 1.4(0.86-2.3 ; p=0.18)$, age $1.0(1.0-1.1 ; p=0.070)$, gender $7.5(3.7-15 ; p<$ $0.001)$, dementia $1.9(1.2-3.1 ; p=0.012)$ and diabetes 2.3 $(1.2-4.5 ; p=0.014)$ (Table 2).

\section{Factors associated with bacteriuria when using cut-off $250 \mathrm{HD}<12.5 \mathrm{nmol} / \mathrm{L}$}

Adjusted OR (95\% CI; p-value) for possible predictors of bacteriuria: $25 \mathrm{OHD}<12.5 \mathrm{nmol} / \mathrm{L} \quad 4.4 \quad(1.1-17 ; \quad p=$ $0.031)$, age $1.0(1.0-1.1 ; p=0.060)$, gender 7.7 (3.8-16; $\mathrm{p}<0.001)$, dementia $1.9(1.2-3.2 ; p=0.010)$ and diabetes $2.4(1.2-4.7 ; \mathrm{p}=0.010)$ (Table 3$)$. 
Table 1 Demographics and serum 25-hydroxyvitamin D (25OHD) concentrations among nursing home residents

\begin{tabular}{llll}
\hline & All residents ${ }^{1}$ & Residents without bacteriuria & Residents with bacteriuria \\
\hline Mean age (SD) & $87(6.7)$ & $86(6.9)$ & $87(5.9)$ \\
Women & $69 \%(266 / 385)$ & $58 \%(153 / 262)$ & $92 \%(113 / 123)$ \\
Dementia & $54 \%(208 / 385)$ & $49 \%(129 / 262)$ & $64 \%(79 / 123)$ \\
Diabetes mellitus & $13 \%(51 / 385)$ & $10 \%(27 / 262)$ & $20 \%(24 / 123)$ \\
Dysuria, urinary urgency or frequency $\leq 1$ week & $1.6 \%(6 / 385)$ & $1.5 \%(4 / 262)$ & $1.6 \%(2 / 123)$ \\
$25 \mathrm{OHD}<12.5 \mathrm{nmol} / \mathrm{L}$ & $3.1 \%(12 / 385)$ & $1.9 \%(5 / 262)$ & $5.7 \%(7 / 123)$ \\
$25 \mathrm{OHD} 12.5$ to $<25 \mathrm{nmol} / \mathrm{L}$ & $34 \%(131 / 385)$ & $33 \%(86 / 262)$ & $37 \%(45 / 123)$ \\
$25 \mathrm{OHD} 25$ to $<50 \mathrm{nmol} / \mathrm{L}$ & $46 \%(176 / 385)$ & $48 \%(126 / 262)$ & $41 \%(50 / 123)$ \\
$25 \mathrm{OHD} 50$ to $<75 \mathrm{nmol} / \mathrm{L}$ & $10 \%(40 / 385)$ & $11 \%(29 / 262)$ & $8.9 \%(11 / 123)$ \\
$25 \mathrm{OHD}>75 \mathrm{nmol} / \mathrm{L}$ & $6.8 \%(26 / 385)$ & $6.1 \%(16 / 262)$ & $8.1 \%(10 / 123)$
\end{tabular}

${ }^{1}$ In total 385 residents: 262 residents without bacteriuria and 123 residents with bacteriuria

\section{Discussion}

Both bacteriuria and vitamin D deficiency were common among the nursing home residents. No association was seen between bacteriuria and $25 \mathrm{OHD}<25 \mathrm{nmol} / \mathrm{L}$. There was an association if using $<12.5 \mathrm{nmol} / \mathrm{L}$ as a cutoff for vitamin D deficiency. However, this finding should be interpreted with caution whereby only a few residents had $<12.5 \mathrm{nmol} / \mathrm{L}$.

\section{Strengths and limitations}

That urine specimens and blood samples were collected from each resident accepting participation and of whom it was possible to get a voided urine specimen and a blood sample from January to March can be considered a strength of this study. Voided urine specimens, blood samples and study protocols were obtained from $43 \%$ $(385 / 901)$ of the residents. Although not large due to dementia and urinary incontinence, this study visited 22 nursing homes and included a similar number of participants as previous studies $[1,6]$.

Another strength of this study is the adjustments for dementia and diabetes, well known confounders. Vitamin D deficiency and bacteriuria are more common among elderly residents at nursing homes with dementia, compared to elderly without $[5,27]$. Also, bacteriuria and UTI are more common in diabetics $[28,29]$. Despite adjusting for these well-known confounders there remains a risk for residual confounding and future research could further consider confounders related to frailty and multimorbidity. There were more women in this study, reflecting gender distribution in nursing homes. We also adjusted for gender in the logistic regressions.

A limitation of this study is that we observed bacteriuria and not UTI, so the clinical relevance of any associations is uncertain. Only a few residents in this study had newly onset symptoms from the urinary tract. Thus, most of the bacteriuric participants had ASB, not UTI. ASB causes a low grade inflammation of the epithelium in the urinary tract, and previous studies have shown an increased frequency of symptomatic UTI in those earlier identified with ASB [22-24]. Due to the increased risk of symptomatic UTI in patients with ASB it is important to study factors potentially associated with ASB. Thus, it may be relevant to study the association between ASB and Vitamin D deficiency.

There was an association between severe vitamin $\mathrm{D}$ deficiency $(25 \mathrm{OHD}<12.5 \mathrm{nmol} / \mathrm{L})$ and bacteriuria. However, there were only 12 residents in this group. Due to

Table 2 Factors associated with bacteriuria, cut-off $25 \mathrm{OHD}^{1}<25 \mathrm{nmol} / \mathrm{L}$

\begin{tabular}{lll}
\hline & Unadjusted odds ratio ${ }^{2}(95 \% \mathrm{Cl} ;$-value $)$ & Adjusted odds ratio $^{3}\left(95 \% \mathrm{Cl}^{\prime} p\right.$-value $)$ \\
\hline Age & $1.4(0.89-2.1 ; p=0.15)$ & $1.4(0.86-2.3 ; p=0.18)$ \\
Gender $^{4}$ & $1.0(1.0-1.1 ; p=0.10)$ & $1.0(1.0-1.1 ; p=0.070)$ \\
Dementia & $8.1(4.0-16 ; \boldsymbol{p}<\mathbf{0 . 0 0 1})$ & $7.5(3.7-15 ; \boldsymbol{p}<\mathbf{0 . 0 0 1})$ \\
Diabetes mellitus & $1.9(1.2-2.9 ; \boldsymbol{p}=\mathbf{0 . 0 0 6 2})$ & $1.9(1.2-3.1 ; \boldsymbol{p}=\mathbf{0 . 0 1 2})$ \\
\hline
\end{tabular}

125-hydroxyvitamin D (25OHD)

${ }^{2} \mathrm{~N}=385$ included in analysis

${ }^{3} \mathrm{~N}=385$ included in analysis. Adjusted logistic regressions with bacteriuria as the dependent variable and the following independent variables: $25 \mathrm{OHD}<25 \mathrm{nmol} /$ $\mathrm{L}$, age, gender, dementia and diabetes mellitus

${ }^{4}$ Reference category: male

Statistically significant findings are bold 
Table 3 Factors associated with bacteriuria, cut-off $25 \mathrm{OHD}^{1}<12.5 \mathrm{nmol} / \mathrm{L}$

\begin{tabular}{|c|c|c|}
\hline & Unadjusted odds ratio ${ }^{2}$ (95\% Cl; p-value) & Adjusted odds ratio ${ }^{3}$ (95\% Cl; p-value) \\
\hline $25 \mathrm{OHD}<12.5 \mathrm{nmol} / \mathrm{L}$ & $3.1(0.96-10 ; p=0.058)$ & $4.4(1.1-17 ; \boldsymbol{p}=\mathbf{0 . 0 3 1})$ \\
\hline Age & $1.0(1.0-1.1 ; p=0.10)$ & $1.0(1.0-1.1 ; p=0.060)$ \\
\hline Gender $^{4}$ & $8.1(4.0-16 ; \boldsymbol{p}<\mathbf{0 . 0 0 1})$ & $7.7(3.8-16 ; \boldsymbol{p}<\mathbf{0 . 0 0 1})$ \\
\hline Dementia & $1.9(1.2-2.9 ; \boldsymbol{p}=\mathbf{0 . 0 0 6 2})$ & $1.9(1.2-3.2 ; \boldsymbol{p}=\mathbf{0 . 0 1 0})$ \\
\hline Diabetes mellitus & $2.1(1.2-3.8 ; \boldsymbol{p}=\mathbf{0 . 0 1 4})$ & $2.4(1.2-4.7 ; \boldsymbol{p}=\mathbf{0 . 0 1 0})$ \\
\hline
\end{tabular}

25-hydroxyvitamin D (25OHD)

${ }^{2} \mathrm{~N}=385$ included in analysis

${ }^{3} \mathrm{~N}=385$ included in analysis. Adjusted logistic regressions with bacteriuria as the dependent variable and the following independent variables: $25 \mathrm{OHD}<12.5$

$\mathrm{nmol} / \mathrm{L}$, age, gender, dementia and diabetes mellitus

${ }^{4}$ Reference category: male

Statistically significant findings are bold

small numbers, this association should be interpreted with caution. When elderly residents become frailer and their general health declines the frequency of ASB increases [30]. They are also more likely to be prone to severe vitamin $\mathrm{D}$ deficiency [31]. We studied the characteristics of these 12 residents to see if there was something that distinguished this group from the other residents: age, gender, dementia or diabetes. In this group 75\% (9/12) had dementia compared to 53\% (199/ 373 ) among those with $25 \mathrm{OHD}>12.5 \mathrm{nmol} / \mathrm{L}$. However, this was not a statistically significant difference $(p=$ 0.14 ), and dementia was adjusted for in the logistic regression. Regarding age, gender and diabetes there were no differences at all between those with 25OHD above or below $12.5 \mathrm{nmol} / \mathrm{L}$. As this is a cross-sectional study it is not possible to evaluate if there is causality between $25 \mathrm{OHD}<12.5 \mathrm{nmol} / \mathrm{L}$ and bacteriuria, or just an association. Since there were only a few patients with severe vitamin $\mathrm{D}$ deficiency it is necessary to evaluate a possible association in a larger study. This research question is strengthened by the effectiveness of vitamin D supplementation in respiratory tract infections; a systematic review and meta-analysis showed reduced risk of acute respiratory tract infections after vitamin $\mathrm{D}$ supplementation, especially in those with baseline $25 \mathrm{OHD}<25 \mathrm{nmol} /$ $\mathrm{L}$ [32]. If an association is confirmed, a randomised controlled trial needs to be carried out to see if substitution with vitamin D could decrease the frequency of ASB, and subsequently also symptomatic UTI, since it is more common in those with ASB. Due to the evolving threat of antibiotic resistance it is important, if possible, to find methods to decrease the number of UTI. Regardless of causality or not there are other reasons for vitamin D supplementation, such as preventing osteoporosis and other conditions, in residents with $25 \mathrm{OHD}<12.5 \mathrm{nmol} /$ L [32-34].

\section{Statistical analysis}

There is no present consensus for optimum serum concentrations of vitamin D $[10,11]$. We chose to calculate the prevalence of vitamin D deficiency by four cut-off values suggested by previous studies and Swedish guidelines: $25 \mathrm{OHD}<12.5 \mathrm{nmol} / \mathrm{L},<25 \mathrm{nmol} / \mathrm{L},<50 \mathrm{nmol} / \mathrm{L}$ and $<75 \mathrm{nmol} / \mathrm{L}$ [5, 35-37]. In the logistic regressions we used 25OHD as a dichotomized variable instead of $25 \mathrm{OHD}$ as a continuous variable: $25 \mathrm{OHD}<25 \mathrm{nmol} / \mathrm{L}$ representing moderate vitamin $\mathrm{D}$ deficiency and $<12.5$ $\mathrm{nmol} / \mathrm{L}$ representing severe vitamin $\mathrm{D}$ deficiency $[5,35$, 36]. This approach was chosen, as we wanted to see if a significant vitamin D deficiency was associated with bacteriuria, without being affected by different concentrations within vitamin D sufficiency. These cut-off values were pre planned in the statistical analysis. However, as a post hoc analysis we also performed a logistic regression using vitamin $\mathrm{D}$ as a continuous variable, and there was no association with bacteriuria $(p=0.47)$. In this analysis we adjusted for the same co-variates as when using 25OHD as a dichotomized variable: age, gender, dementia and diabetes mellitus.

\section{Conclusions}

Bacteriuria was common among residents as well as vitamin $\mathrm{D}$ deficiency. There was no association between bacteriuria and $25 \mathrm{OHD}<25 \mathrm{nmol} / \mathrm{L}$. If using $<12.5$ $\mathrm{nmol} / \mathrm{L}$ as a cut-off for vitamin D deficiency, an association was seen. However, this finding has to be interpreted with caution as causality cannot be evaluated as well as only a few residents had $25 \mathrm{OHD}<12.5 \mathrm{nmol} / \mathrm{L}$. This has to be evaluated in a future study including more residents with severe vitamin D deficiency.

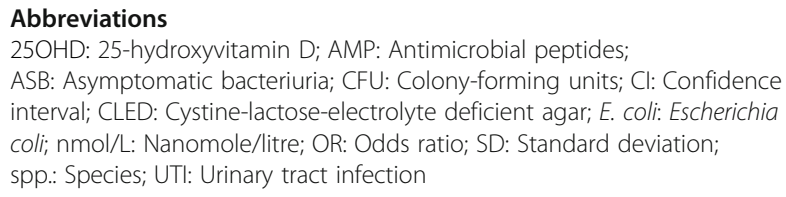
Bio Imaging and Laboratory Medicine Unit, Södra Älvsborg Hospital. 


\section{Authors' contributions}

PDS and ME participated in the design of the study and carried out the data collection. RA, ESA and PDS drafted the manuscript. RA, ESA, JT, ME, MM and PDS contributed to interpretation of the data and analysis, critical reviews and revisions, and the final approval of the paper. All authors have read and approved the manuscript.

\section{Funding}

Financial support was obtained from primary health care in Södra Älvsborg County, the Research and Development Council of the Södra Älvsborg County, and FoU Sjuhärad Välfärd (a research and development unit in Borås). Sponsors did not influence the design, methods, subject recruitment, data collection, analysis or preparation of the manuscript. Open access funding provided by University of Gothenburg.

\section{Availability of data and materials}

The data that supports the findings of this study is available from the corresponding author upon request.

\section{Ethics approval and consent to participate}

The study was approved by the Regional ethical review board of Gothenburg University (reference number 578-11). Statement of consent: Included residents were provided both written and verbal information. Informed approval was obtained from decision-capable individuals. Written informed consent was the standard procedure. If physical disability prevented the participant from personally signing, the attending nurse affirmed with a signature that informed verbal consent was obtained. However, many participants had varying forms of dementia. If a resident lacked comprehension of the provided information, they participated only if they or their surrogates, such as s spouse or child/children, did not refuse participation after the provision of information regarding the study. This procedure was approved by the Regional ethical review board of Gothenburg University.

\section{Consent for publication}

Not applicable.

\section{Competing interests}

The authors declare no competing interests.

\section{Author details}

'Research and Development Primary Health Care, Region Västra Götaland, Research and Development Centre Södra Älvsborg Sweden, Sven Eriksonsplatsen 4, SE-503 38 Borås, Sweden. ${ }^{2}$ Department of Public Health and Community Medicine/Primary Health Care, Institute of Medicine, Sahlgrenska Academy at the University of Gothenburg, Box 454, SE-405 30 Gothenburg, Sweden. ${ }^{3}$ Närhälsan Heimdal Health Care Center, Stengärdsgatan 22, SE-503 34 Borås, Sweden. ${ }^{4}$ Närhälsan Fristad Health Care Center, Tärnavägen 6, SE-513 33 Fristad, Borås, Sweden. ${ }^{5}$ Health Care Unit Borås Municipality, Ramnåsgatan 1, SE-501 80 Borås, Sweden. ${ }^{6}$ Academic Unit of Primary Care and Population Sciences, Faculty of Medicine, University of Southampton, Aldermoor Health Centre, Aldermoor Close, Southampton SO16 5ST, UK. Närhälsan Sandared Health Care Center, Strandvägen 11, SE-518 32 Sandared, Borås, Sweden.

Received: 3 September 2019 Accepted: 19 December 2019 Published online: 30 December 2019

\section{References}

1. Hedin K, Petersson C, Wideback K, Kahlmeter G, Molstad S. Asymptomatic bacteriuria in a population of elderly in municipal institutional care. Scand J Prim Health Care. 2002;20(3):166-8.

2. Sundvall PD, Gunnarsson RK. Evaluation of dipstick analysis among elderly residents to detect bacteriuria: a cross-sectional study in 32 nursing homes. BMC Geriatr. 2009;9:32.

3. Rowe TA, Juthani-Mehta M. Urinary tract infection in older adults. Aging Health. 2013;9(5)

4. Meehan M, Penckofer S. The Role of Vitamin D in the Aging Adult. J Aging Gerontol. 2014;2(2):60-71.

5. Arnljots R, Thorn J, Elm M, Moore M, Sundvall PD. Vitamin D deficiency was common among nursing home residents and associated with dementia: a cross sectional study of 545 Swedish nursing home residents. BMC Geriatr. 2017;17(1):229.

6. Samefors M, Ostgren CJ, Molstad S, Lannering C, Midlov P, Tengblad A. Vitamin D deficiency in elderly people in Swedish nursing homes is associated with increased mortality. Eur J Endocrinol. 2014;170(5):667-75.

7. Egsmose $C$, Lund B, McNair $P$, Lund B, Storm $T$, Sorensen $O H$. Low serum levels of 25-hydroxyvitamin D and 1,25-dihydroxyvitamin $D$ in institutionalized old people: influence of solar exposure and vitamin D supplementation. Age Ageing. 1987;16(1):35-40.

8. Bruyere O, Decock C, Delhez M, Collette J, Reginster JY. Highest prevalence of vitamin $D$ inadequacy in institutionalized women compared with noninstitutionalized women: a case-control study. Women's Health (London, England). 2009;5(1):49-54.

9. Burgaz A, Akesson A, Oster A, Michaelsson K, Wolk A. Associations of diet, supplement use, and ultraviolet B radiation exposure with vitamin D status in Swedish women during winter. Am J Clin Nutr. 2007;86(5):1399-404.

10. Fuleihan Gel H, Bouillon R, Clarke B, Chakhtoura M, Cooper C, McClung M, Singh RJ. Serum 25-Hydroxyvitamin D Levels: Variability, Knowledge Gaps, and the Concept of a Desirable Range. J Bone Miner Res. 2015;30(7):1119-33.

11. Brouwer-Brolsma EM, Bischoff-Ferrari HA, Bouillon R, Feskens EJ, Gallagher CJ, Hypponen E, Llewellyn DJ, Stoecklin E, Dierkes J, Kies AK, et al. Vitamin D: do we get enough? A discussion between vitamin D experts in order to make a step towards the harmonisation of dietary reference intakes for vitamin D across Europe. Osteoporos Int. 2013;24(5):1567-77.

12. Hertting $\mathrm{O}$, Holm A, Luthje $P$, Brauner $H$, Dyrdak $R$, Jonasson AF, Wiklund $P$, Chromek M, Brauner A. Vitamin D induction of the human antimicrobial Peptide cathelicidin in the urinary bladder. PLoS One. 2010;5(12):e15580

13. Schwalfenberg GK. A review of the critical role of vitamin $D$ in the functioning of the immune system and the clinical implications of vitamin D deficiency. Mol Nutr Food Res. 2011:55(1):96-108.

14. Zasloff M. Antimicrobial peptides, innate immunity, and the normally sterile urinary tract. J Am Soc Nephrol. 2007:18(11):2810-6.

15. Chromek M, Slamova Z, Bergman P, Kovacs L, Podracka L, Ehren I, Hokfelt T, Gudmundsson GH, Gallo RL, Agerberth B, et al. The antimicrobial peptide cathelicidin protects the urinary tract against invasive bacterial infection. Nat Med. 2006:12(6):636-41.

16. Kwon YE, Kim H, Oh HJ, Park JT, Han SH, Ryu DR, Yoo TH, Kang SW. Vitamin $D$ deficiency is an independent risk factor for urinary tract infections after renal transplants. Med(Baltimore). 2015;94(9):e594.

17. Ramos NL, Sekikubo M, Kironde F, Mirembe F, Saaf M, Brauner A. The impact of vitamin D on the innate immune response to uropathogenic Escherichia coli during pregnancy. Clin Microbiol Infect. 2015;21(5):482.e481-7.

18. Ovunc Hacihamdioglu D, Altun D, Hacihamdioglu B, Cekmez F, Aydemir G, Kul M, Muftuoglu T, Suleymanoglu S, Karademir F. The Association between Serum 25-Hydroxy Vitamin D Level and Urine Cathelicidin in Children with a Urinary Tract Infection. J Clin Res Pediatr Endocrinol. 2016;8(3):325-9.

19. Nseir W, Taha M, Nemarny H, Mograbi J. The association between serum levels of vitamin $D$ and recurrent urinary tract infections in premenopausal women. Int J Infect Dis. 2013:17(12):e1121-4.

20. Oberg J, Verelst M, Jorde R, Cashman K, Grimnes G. High dose vitamin D may improve lower urinary tract symptoms in postmenopausal women. J Steroid Biochem Mol Biol. 2017;173:28-32.

21. Jorde R, Sollid ST, Svartberg J, Joakimsen RM, Grimnes G, Hutchinson MY. Prevention of urinary tract infections with vitamin $D$ supplementation 20,000 IU per week for five years. Results from an RCT including 511 subjects. Infect Dis (London, England). 2016;48(11-12):823-8.

22. Alwall N. On controversial and open questions about the course and complications of non-obstructive urinary tract infection in adult women. Follow-up for up to 80 months of 707 participants in a population study and evaluation of a clinical series of 36 selected women with a history of urinary tract infection for up to 40 years. Acta Med Scand. 1978;203(5):369-77.

23. Tencer J. Asymptomatic bacteriuria--a long-term study. Scand J Uro Nephrol. 1988;22(1):31-4

24. Nicolle LE, Gupta K, Bradley SF, Colgan R, DeMuri GP, Drekonja D, Eckert LO, Geerlings SE, Koves B, Hooton TM, et al. Clinical Practice Guideline for the Management of Asymptomatic Bacteriuria: 2019 Update by the Infectious Diseases Society of Americaa. Clin Infect Dis. 2019

25. Sundvall PD, Elm M, Ulleryd P, Molstad S, Rodhe N, Jonsson L, Andersson B, Hahn-Zoric M, Gunnarsson R. Interleukin-6 concentrations in the urine and dipstick analyses were related to bacteriuria but not symptoms in the elderly: a cross sectional study of 421 nursing home residents. BMC Geriatr. 2014;14:88. 
26. Sundvall PD, Elm M, Gunnarsson R, Molstad S, Rodhe N, Jonsson L, Ulleryd $P$. Antimicrobial resistance in urinary pathogens among Swedish nursing home residents remains low: a cross-sectional study comparing antimicrobial resistance from 2003 to 2012. BMC Geriatr. 2014;14:30.

27. Marschall J, Piccirillo ML, Foxman B, Zhang L, Warren DK, Henderson JP. Patient characteristics but not virulence factors discriminate between asymptomatic and symptomatic E. coli bacteriuria in the hospital. BMC Infect Dis. 2013;13:213.

28. Zhanel GG, Nicolle LE, Harding GK. Prevalence of asymptomatic bacteriuria and associated host factors in women with diabetes mellitus. The Manitoba Diabetic Urinary Infection Study Group. Clin Infect Dis. 1995;21(2):316-22.

29. Boyko EJ, Finn SD, Scholes D, Abraham L, Monsey B. Risk of urinary tract infection and asymptomatic bacteriuria among diabetic and nondiabetic postmenopausal women. Am J Epidemiol. 2005;161 (6):557-64.

30. Ariathianto Y. Asymptomatic bacteriuria - prevalence in the elderly population. Aust Fam Physician. 2011;40(10):805-9.

31. Ju SY, Lee JY, Kim DH. Low 25-hydroxyvitamin D levels and the risk of frailty syndrome: a systematic review and dose-response meta-analysis. BMC Geriatr. 2018;18(1):206

32. Martineau AR, Jolliffe DA, Hooper RL, Greenberg L, Aloia JF, Bergman P, Dubnov-Raz G, Esposito S, Ganmaa D, Ginde AA, et al. Vitamin D supplementation to prevent acute respiratory tract infections: systematic review and meta-analysis of individual participant data. BMJ. 2017;356:6583.

33. Weaver CM, Alexander DD, Boushey CJ, Dawson-Hughes B, Lappe JM, LeBoff MS, Liu S, Looker AC, Wallace TC, Wang DD. Calcium plus vitamin D supplementation and risk of fractures: an updated meta-analysis from the National Osteoporosis Foundation. Osteoporos Int. 2016;27(1):367-76.

34. Jolliffe DA, Greenberg L, Hooper RL, Griffiths CJ, Camargo CA Jr, Kerley CP, Jensen ME, Mauger D, Stelmach I, Urashima M, et al. Vitamin D supplementation to prevent asthma exacerbations: a systematic review and meta-analysis of individual participant data. Lancet Respir Med. 2017;5(11): 881-90.

35. Lips P. Vitamin D deficiency and secondary hyperparathyroidism in the elderly: consequences for bone loss and fractures and therapeutic implications. Endocr Rev. 2001:22(4):477-501.

36. Lips P, Duong T, Oleksik A, Black D, Cummings S, Cox D, Nickelsen T. A global study of vitamin D status and parathyroid function in postmenopausal women with osteoporosis: baseline data from the multiple outcomes of raloxifene evaluation clinical trial. J Clin Endocrinol Metab. 2001;86(3):1212-21.

37. Lorentzon M, Akesson K, Mellstrom D, Landin-Wilhelmsen K, Pernow Y Bergstrom I, Ljunggren O. D-vitaminbehandling och skeletthälsa - svenska riktlinjer behövs. Lakartidningen. 2014;111(CW6C).

\section{Publisher's Note}

Springer Nature remains neutral with regard to jurisdictional claims in published maps and institutional affiliations.

Ready to submit your research? Choose BMC and benefit from:

- fast, convenient online submission

- thorough peer review by experienced researchers in your field

- rapid publication on acceptance

- support for research data, including large and complex data types

- gold Open Access which fosters wider collaboration and increased citations

- maximum visibility for your research: over $100 \mathrm{M}$ website views per year

At $\mathrm{BMC}$, research is always in progress.

Learn more biomedcentral.com/submissions 